\title{
The Vertical Distribution of Marine Macroplankton IV. The Apparent Importance of Light Intensity as a Controlling Factor in the Behaviour of Certain Species in the Plymouth Area.
}

By

\author{
F. S. Russell, D.S.C., B.A., \\ Assistant Naturalist at the Plymouth Laboratory.
}

With 7 Figures in the Text.

\section{INTRODUCTION.}

IF, on a day in the summer, we take a series of collections of plankton from different depths, in full daylight, in water about 50 metres deep a few miles beyond the Plymouth Breakwater, we find that the plankton exhibits an ordered vertical distribution. In the upper 6 or 7 metres plankton animals are scarce, and then suddenly an increase in their abundance takes place, which exists nearly to the bottom. Analysis of the catches, however, shows that the various species that compose the plankton do not all appear to adopt the same type of vertical distribution; in fact, the total plankton distribution is the sum of a number of different types of distribution. If we look at a table recording the numbers of different species caught at, say, six depths, we find that as we go deeper new species appear in the catches that were not represented in the collections from the layers above.

If we repeat the above experiment on different days, we find that the type of vertical distribution shown by each species is fairly consistently the same from day to day with relation to that of the other species, though the actual depth units may vary.

Fig. 1 gives the vertical distribution shown by about ten different species on three separate days. The diagrams are based on results obtained by collections with the stramin ring-trawl, the fishing depths of which have been obtained by a graphic depth-recorder. In each case six different depths were sampled. The figure shows the percentage vertical distribution for each species, i.e. each catch is expressed as a percentage of the total number of that species caught at all six depths. Table 1 gives the actual numbers and percentages for the three different days. 

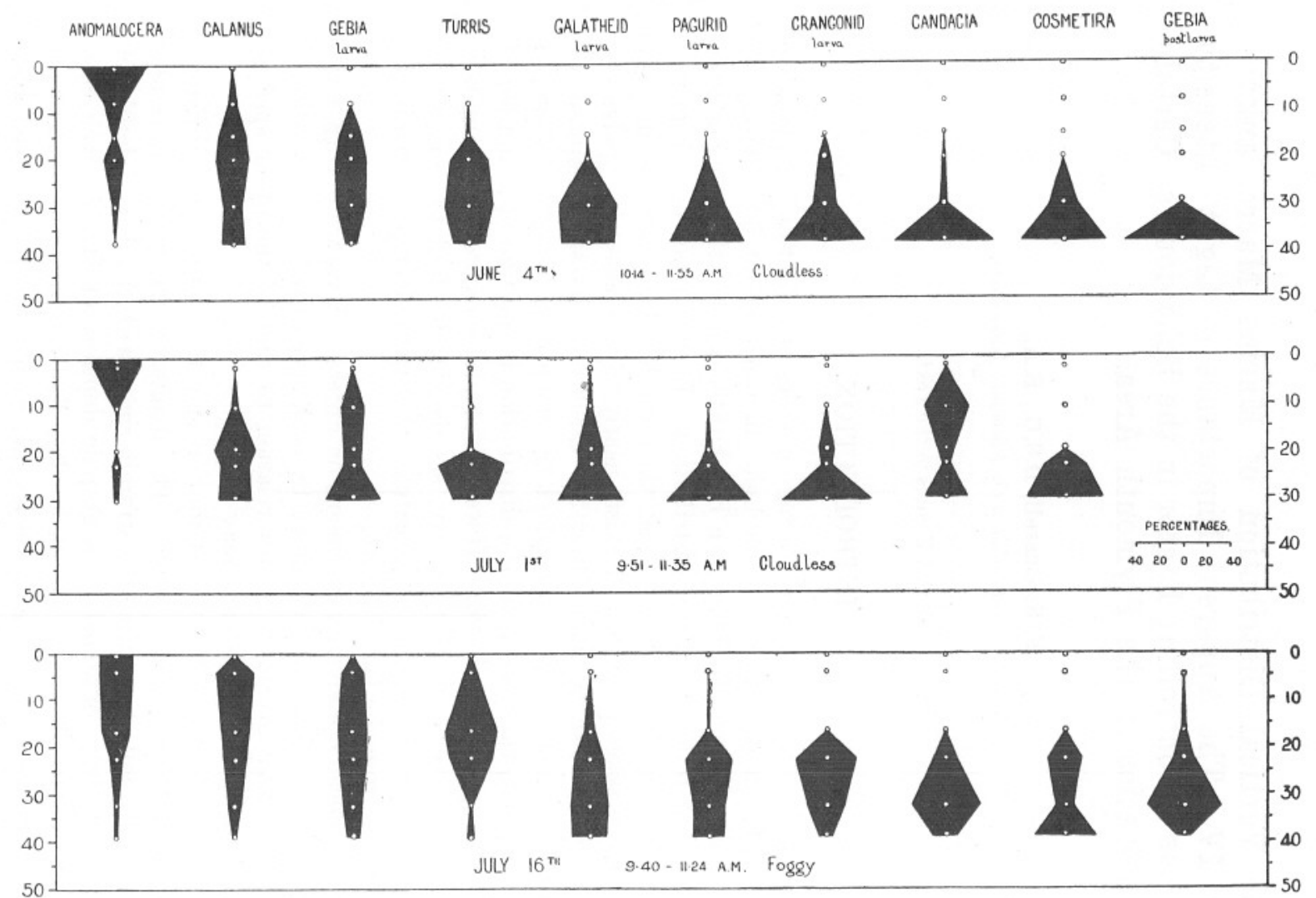

FIG. 1.-The percentage vertical distribution of the above-named species on June 4th, July 1st, and July 16th, respectively' in water more than 50 metres deep as shown by collections with the stramin ring-trawl. The depths are in metres the white spots and black rings indicate the average depths at which hauls were taken. 
TABLE 1.

June 4th, 1925. 10·14-11·55 A.M. Bright Sunshine.

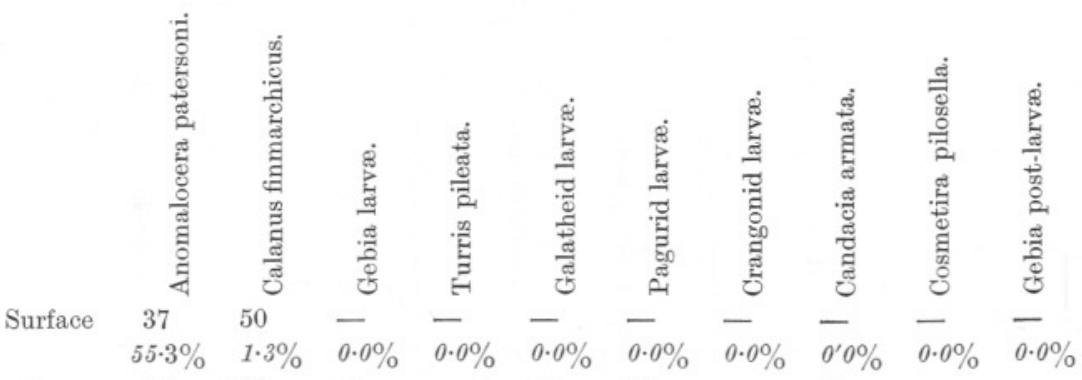

$\begin{array}{lllllllllll}8 \mathrm{~m} . & 12 & 320 & 20 & - & 10 & 10 & - & 10 & - & - \\ & 18 \% & 8.2 \% & 1.4 \% & 0.0 \% & 0.1 \% & 0.3 \% & 0.0 \% & 2.7 \% & 0.0 \% & 0.0 \%\end{array}$

$\begin{array}{cclllllllll}15 \mathrm{~m} . & 3 & 960 & 260 & 16 & 60 & - & - & - & - & - \\ & 4 \cdot 4 \% & 24.7 \% & 19 \cdot 3 \% & 3.7 \% & 0.9 \% & 0.0 \% & 0.0 \% & 0.0 \% & 0.0 \% & 0.0 \%\end{array}$

$\begin{array}{lllllllllll}20 \mathrm{~m} . & 12 & 1060 & 620 & 136 & 200 & 70 & 5 & 20 & - & - \\ & 18 \% & 27.3 \% & 45 \cdot 9 \% & 31 \cdot 1 \% & 3 \cdot 2 \% & 2 \cdot 7 \% & 11 \cdot 7 \% & 5 \cdot 4 \% & 0 \cdot 0 \% & 0 \cdot 0 \%\end{array}$

$\begin{array}{cclllllllll}30 \mathrm{~m} . & 3 & 650 & 330 & 170 & 3120 & 810 & 8 & 30 & 322 & - \\ & 4 \cdot 4 \% & 16 \cdot 7 \% & 24 \cdot 5 \% & 39 \cdot 1 \% & 49 \cdot 9 \% & 31 \cdot 2 \% & 18 \cdot 6 \% & 8 \cdot 1 \% & 25 \cdot 6 \% & 0 \cdot 0 \%\end{array}$

$\begin{array}{lllllllllll}38 \mathrm{~m} . & - & 850 & 120 & 114 & 2870 & 1710 & 30 & 310 & 938 & 2\end{array}$

$\begin{array}{lllllllllll}0.0 & 0 & 21 \cdot 8 \% & 8 \cdot 8 \% & 26 \cdot 2 \% & 45 \cdot 9 \% & 65 \cdot 8 \% & 69 \cdot 8 \% & 83 \cdot 8 \% & 74 \cdot 4 \% & 100 \%\end{array}$

July 1st, 1925. 9.51-11.35 A.M. Bright Sunshine.

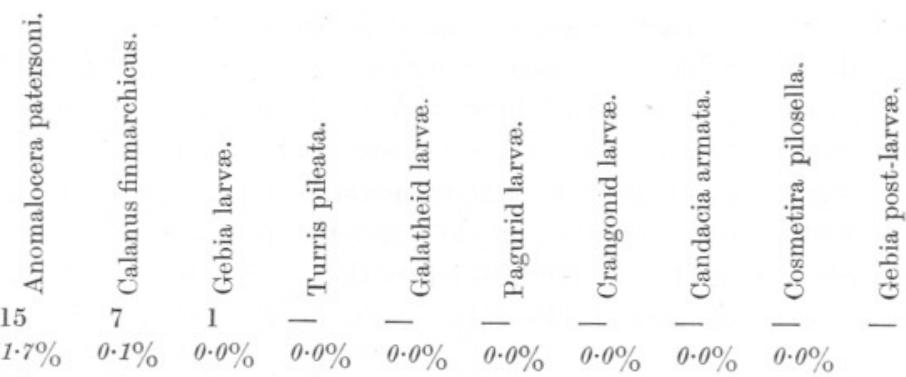

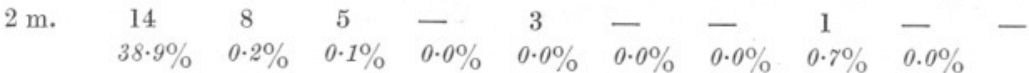
$\begin{array}{cccccccccc}11 \mathrm{~m} . & 2 & 380 & 740 & 17 & 160 & - & - & 60 & - \\ & 5 \cdot 5 \% & 9 \cdot 4 \% & 19 \cdot 1 \% & 2 \cdot 3 \% & 3 \cdot 7 \% & 0 \cdot 0 \% & 0 \cdot 0 \% & 42 \cdot 6 \% & 0 \cdot 0 \%\end{array}$

$\begin{array}{lllllllllll}19 \cdot 8 \mathrm{~m} . & - & 1510 & 620 & 50 & 960 & 10 & 40 & 20 & - & - \\ & 0 \cdot 0 \% & 37 \cdot 2 \% & 16 \% & 7 \cdot 0 \% & 22 \cdot 2 \% & 7 \cdot 1 \% & 14 \cdot 3 \% & 14 \cdot 2 \% & 0 \cdot 0 \%\end{array}$

$\begin{array}{lllllllllll}23 \cdot 1 \mathrm{~m} . & 3 & 960 & 590 & 410 & 830 & 30 & 30 & 10 & 19 & -\end{array}$

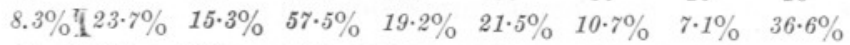

$\begin{array}{lllllllllll}30 \cdot 2 \mathrm{~m} . & 2 & 1190 & 1910 & 237 & 2370 & 100 & 210 & 50 & 33 & -\end{array}$

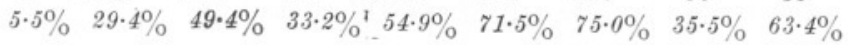


TABLE I.-continued.

July $16 \mathrm{TH}, 1925 . \quad 9 \cdot 40-11 \cdot 24$ A.M. Foggy.

\begin{tabular}{|c|c|c|c|c|c|c|c|c|c|c|}
\hline & 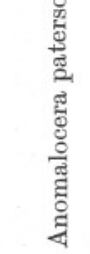 & 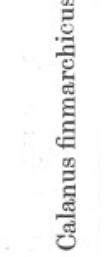 & 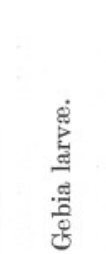 & 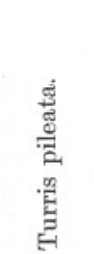 & 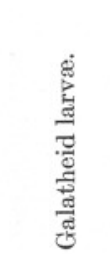 & 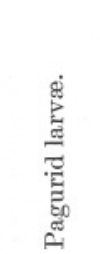 & 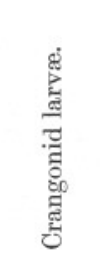 & 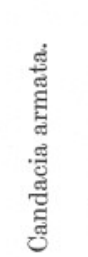 & 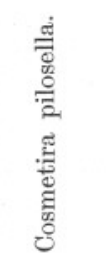 & 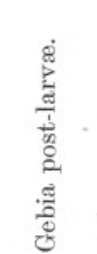 \\
\hline Surface & $\begin{array}{c}52 \\
29 \cdot 6 \%\end{array}$ & $\begin{array}{l}157 \\
0.9 \%\end{array}$ & $\begin{array}{l}25 \\
0 \cdot 3 \%\end{array}$ & $\overline{0.0 \%}$ & $\overline{0.0 \%}$ & $\overline{0.0 \%}$ & $\overline{0.0 \%}$ & $\overline{0.0 \%}$ & $\overline{0.0 \%}$ & $\overline{0.0 \%}$ \\
\hline $4 \mathrm{~m}$. & $\begin{array}{c}46 \\
26 \cdot 1 \%\end{array}$ & $\begin{array}{l}5450 \\
33 \cdot 4 \%\end{array}$ & $\begin{array}{l}1530 \\
21 \cdot 2 \%\end{array}$ & $\begin{array}{c}10 \\
11 \cdot 5 \%\end{array}$ & $\overline{0.0 \%}$ & $\overline{0.0 \%}$ & $\overline{0.0 \%}$ & $\overline{0.0 \%}$ & $\overline{0.0 \%}$ & $\overline{0.0 \%}$ \\
\hline $16.5 \mathrm{~m}$. & $\begin{array}{c}44 \\
25 \cdot 1 \%\end{array}$ & $\begin{array}{l}4140 \\
25 \cdot 4 \%\end{array}$ & $\begin{array}{l}1870 \\
25.9 \%\end{array}$ & $\begin{array}{c}38 \\
43 \cdot 7 \%\end{array}$ & $\begin{array}{l}320 \\
9 \cdot 7 \%\end{array}$ & $\begin{array}{l}20 \\
3 \cdot 3 \%\end{array}$ & $\overline{0.0} \%$ & $\overline{0.0 \%}$. & $\begin{array}{c}1 \\
0.2 \%\end{array}$ & $\begin{array}{c}1 \\
6 \cdot 2 \%\end{array}$ \\
\hline $22.2 \mathrm{~m}$. & $\begin{array}{c}20 \\
11 \cdot 4 \%\end{array}$ & $\begin{array}{l}3420 \\
21 \cdot 1 \%\end{array}$ & $\begin{array}{l}1760 \\
24 \cdot 4 \%\end{array}$ & $\begin{array}{c}30 \\
34 \cdot 5 \%\end{array}$ & $\begin{array}{l}880 \\
26 \cdot 6 \%\end{array}$ & $\begin{array}{l}240 \\
40 \cdot 7 \%\end{array}$ & $\begin{array}{c}80 \\
53 \cdot 3 \%\end{array}$ & $\begin{array}{l}20 \\
20 \%\end{array}$ & $\begin{array}{l}173 \\
30 \cdot 4 \%\end{array}$ & $\begin{array}{c}3 \\
18 \cdot 8 \%\end{array}$ \\
\hline $32 \cdot 3 \mathrm{~m}$. & $\begin{array}{c}7 \\
3.9 \%\end{array}$ & $\begin{array}{l}2070 \\
12 \cdot 7 \%\end{array}$ & $\begin{array}{l}1100 \\
15 \cdot 3 \%\end{array}$ & $\begin{array}{c}3 \\
3 \cdot 4 \%\end{array}$ & $\begin{array}{l}1130 \\
34 \cdot 2 \%\end{array}$ & $\begin{array}{l}170 \\
28.9 \%\end{array}$ & $\begin{array}{c}50 \\
33 \cdot 3 \%\end{array}$ & $\begin{array}{l}60 \\
60 \%\end{array}$ & $\begin{array}{c}94 \\
16.5 \%\end{array}$ & $\begin{array}{c}10 \\
62 \cdot 5 \%\end{array}$ \\
\hline $38.8 \mathrm{~m}$. & $\begin{array}{c}7 \\
3.9 \%\end{array}$ & $\begin{array}{l}1040 \\
\quad 6.4 \%\end{array}$ & $\begin{array}{l}920 \\
12.8 \%\end{array}$ & $\begin{array}{c}6 \\
6.9 \%\end{array}$ & $\begin{array}{l}980 \\
29 \cdot 6 \%\end{array}$ & $\begin{array}{l}160 \\
27 \cdot 2 \%\end{array}$ & $\begin{array}{l}20 \\
13 \cdot 3 \%\end{array}$ & $\begin{array}{l}20 \\
20 \%\end{array}$ & $\begin{array}{l}301 \\
52.9 \%\end{array}$ & $\begin{array}{c}2 \\
12 \cdot 5 \%\end{array}$ \\
\hline
\end{tabular}

It will be seen from this table and from Fig. 1 that these species exhibit fairly constant types of vertical distribution relative to one another. That there are discrepancies is natural, owing to the unevenness in horizontal distribution that may bring in errors large enough to distort the true picture of the vertical distribution. The presence of Candacia armata high in the water on July 1st is unusual: it can be seen from the table, however, that the numbers were rather small to be significant, these being obtained by examining a sample one-tenth of the whole catch. It may well have been that below 30 metres they were far more numerous. On the same day between $12 \cdot 25$ and $2 \cdot 6 \mathrm{p}$.m. the numbers were for this species :

$\begin{array}{cccccc}\text { Surface } & 3.5 \mathrm{~m} . & 8.8 \mathrm{~m} . & 21.3 \mathrm{~m} . & 27 \cdot 1 \mathrm{~m} . & 36.7 \mathrm{~m} . \\ 2 & - & - & - & 20 & 120\end{array}$

These figures show an increase below 30 metres.

The order in which the species have been placed in the figure and table is based on an examination of seventeen separate stations of a similar nature, the general impression thus given being that they show a gradual descent in the region of their maximum abundance. These are, of course, only ten of the thirty or forty different species that 
occur in the collections. The actual results for all the stations will be given in a future paper.

It will be noticed also in Fig. 1 that many species are considerably higher in the water on July 16th than on June 4th. The significance of this will be discussed later.

\section{Comparison between the Vertical Distribution of certain Species IN RELATION TO LIGHT.}

Let us for the moment put aside all outside factors that may affect the vertical distribution of any one species, except the factor, light intensity. Of all the changing factors that make up the environment of the organism in offshore waters in this region this shows the greatest. range of variation. Now let us suppose that an animal has a so-called optimum intensity of illumination, that is, that if given a range of in-

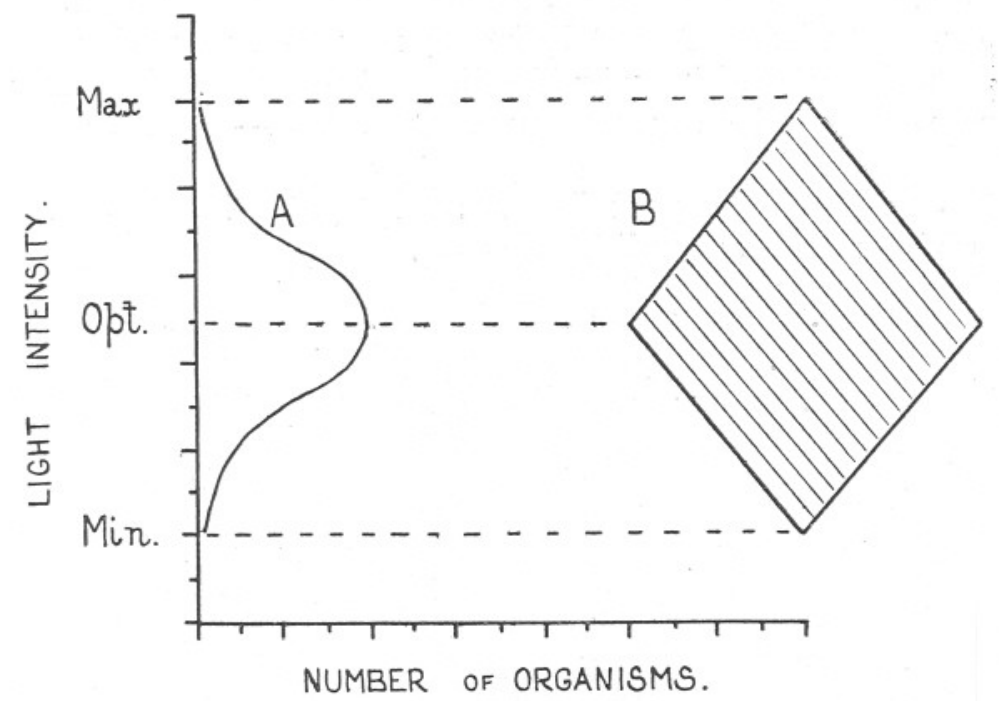

FIG. 2.-A, Hypothetical distribution curve. B, Distribution figure that would be obtained if hauls were taken with a net at the points of maximum, optimum, and minimum abundance.

tensities to choose from it would select this optimum ; by what mechanism this is brought about does not concern us at the present. Let us assume also that besides having an optimum intensity it has also a range of illumination outside which for some unknown reason it does not elect to pass : it will then have a maximum intensity of illumination and a minimum. Let us also assume that the maximum and minimum occur equidistant in light intensity units from the optimum. We should then imagine its distribution to be that of the order shown by the curve A in 
Fig. 2. (A similar curve for vertical distribution has been suggested by Rose, 12, p. 529.) If the light intensity units be also regarded as depth units, and if collections are made by the net in the region of the maximum, optimum and minimum light intensities, we shall obtain a symmetrical distribution figure* as that marked B (Fig. 2).

Now we know that the intensity of light in the sea does not decrease in direct proportion with the depth, but that it decreases in geometrical progression. That is, for every metre of depth the same fraction of the light present a metre above is absorbed. If, for instance, we have at the surface 100 units of light, and if at a depth of 1 metre there are 50 units, then at a depth of 2 metres there will be $\frac{50}{2}$ units, at 3 metres $\frac{25}{2}$, and at 4 metres $\frac{12 \cdot 5}{2}$, and so on ; this is, of course, for pure water.

In Fig. 3, curve A represents the actual illumination in the sea, twenty miles off the coast of Plymouth, at different depths in October. This curve was drawn from figures obtained by means of a photo-electric cell, with maximum sensitivity for blue light (Poole and Atkins, 10), the actual readings being as follows (from 10, p. 192) :-

October 1st, 1925. E1 (ten miles S.W. of Eddystone Lighthouse). Sea surface : glassy, very slight oily swell.

\begin{tabular}{|c|c|c|c|c|}
\hline \multicolumn{2}{|c|}{ Time. } & Light. & \multirow{2}{*}{$\begin{array}{c}\text { Depth. } \\
\text { Air }\end{array}$} & $\%$ light. \\
\hline 2.11 & p.m. & Weak Sun & & $100 \dagger$ \\
\hline 1.58 & , & $\quad, \quad$, & 1.5 & $71 \cdot 2$ \\
\hline 1.46 & , & ", & $6 \cdot 1$ & $41 \cdot 2$ \\
\hline 1.18 & , & , & $8 \cdot 9$ & $28 \cdot 3$ \\
\hline 12.53 & , &,$\quad$, & $12 \cdot 2$ & $18 \cdot 6$ \\
\hline 12.40 & , & Dull & $18 \cdot 3$ & 7.92 \\
\hline 12.31 & , & , & $24 \cdot 4$ & $2 \cdot 93$ \\
\hline $\begin{array}{r}12.19 \\
1.35\end{array}$ & & Weak Su & $34 \cdot 8$ & \\
\hline
\end{tabular}

Suppose that the optimum intensity for a certain animal be 35 units and that it has a range of 65 units: then, if the optimum lies midway between the maximum and minimum, the maximum will have a value of 67.5 and the minimum 2.5 units. From the curve, in Fig. 3, we can see that the maximum intensity will be found at a depth of about 2 metres. just over 5 metres above the depth at which the optimum occurs, i.e,

* In all figures illustrating vertical distribution straight lines, 'rather than arbitrary probability curves, have been drawn between the points, the depths at which hauls are made not being sufficiently close at times to allow of any nearer approximation.

+ Percentage of light transmitted by actual surface was $95 \%$. 
$7.5 \mathrm{~m}$. The minimum intensity, however, will be very much further than the maximum from the optimum in depth units, at about 26.5 metres, i.e. 19 metres below the optimum. If then we take collections from 2 metres, $7.5 \mathrm{~m}$. and $26.5 \mathrm{~m}$., i.e. in the regions of maximum, optimum,

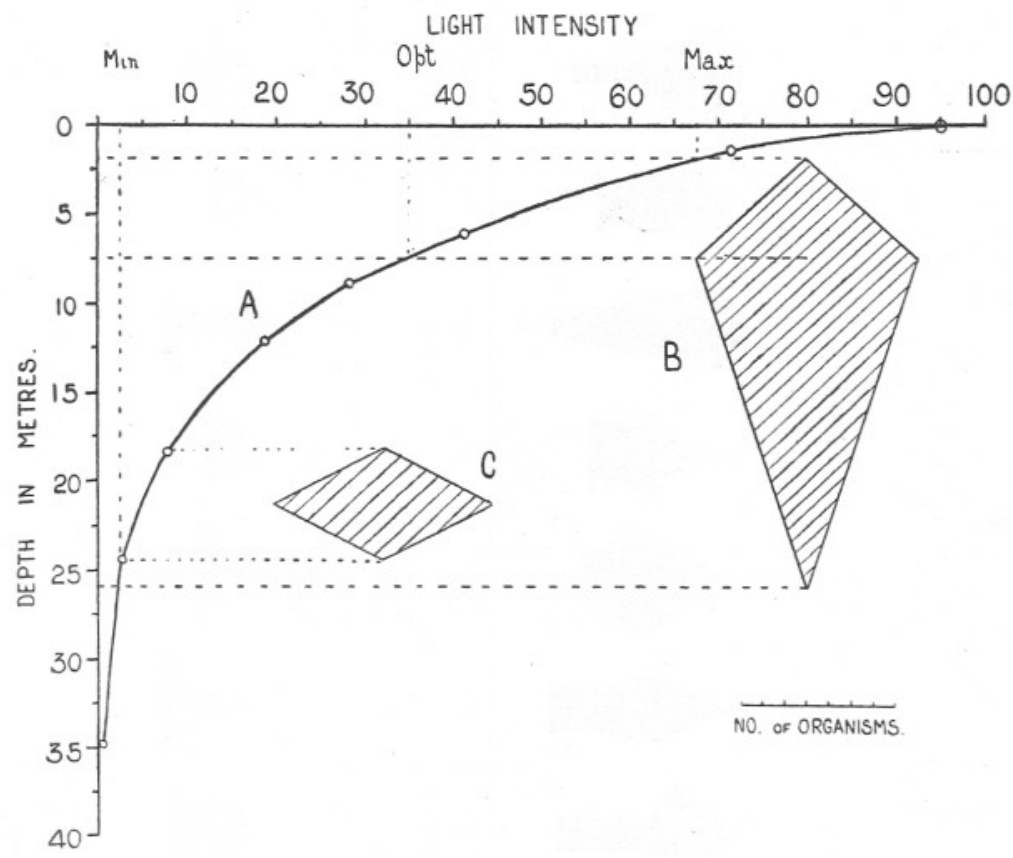

FIG. 3.-A, Curve of percentage light intensity at the international Station El on Oct. 1st, 1925, from figures obtained by Poole and Atkins, 10. B, Vertical distribution diagram of an organism having a high optimum light intensity and living through a wide range of intensities. C, Vertical distribution diagram of an organism having a low optimum light intensity and living through a narrow range of intensities.

and minimum intensities, we shall get a distribution figure of the type shown, B. At whatever depth the optimum occurs if the ratio $\frac{\text { range }}{\text { optimum }}=$
67.5 $\frac{67 \cdot 5}{35}$ we shall get approximately the same type of distribution. The smaller the value $\frac{\text { range }}{\text { optimum }}$ becomes, however, the more nearly symmetrical will the distribution figure be. This is exemplified by $\mathrm{C}$, which shows the distribution of an organism whose optimum is 5 light intensity units and range 5 units, i.e. $2 \cdot 5$ to $7 \cdot 5$, so that the ratio $\frac{\text { range }}{\text { optimum }}=\frac{5}{5}=1$.

Fig. 4 gives some of the types of distribution shown by the copepod, Calanus finmarchicus, and the medusa, Cosmetira pilosella, at different 

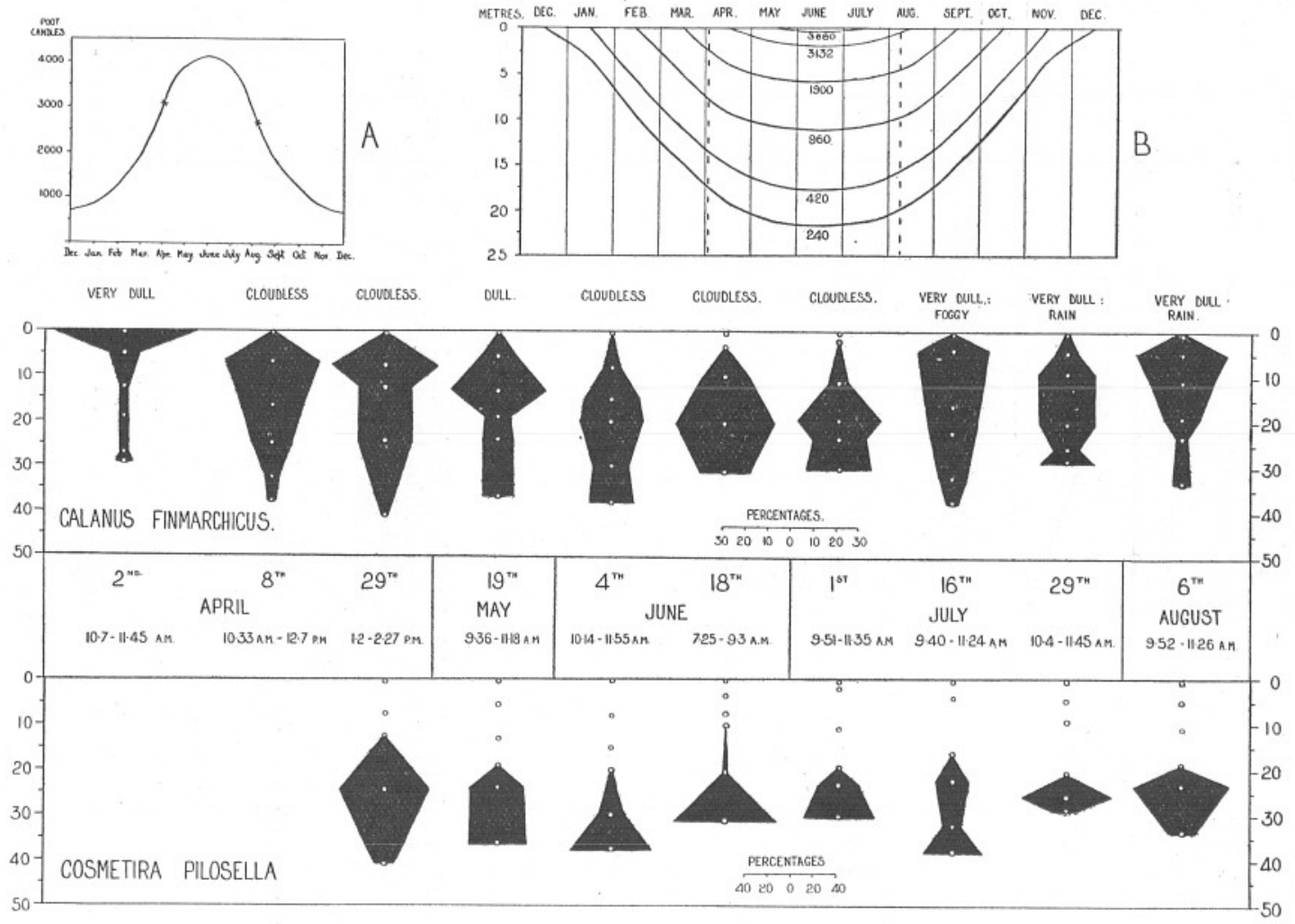

FIG. 4.-A, Curve of seasonal change in light intensity (skylight) in air (from Dictionary of Applied Physics). $B$, Seasonal iso-intensity curves of light plotted against depth: the intensities are in foot candles. The lowe portion of the figure shows the vertical distribution of Calanus finmarchicus and Cosmetira pilosella on different days in water over 50 metres in depth. The white spots and black circles indicate the averae depths at which hauls were made. 
dates between April and August, in daylight, drawn from results obtained by taking plankton samples at six different depths. Calanus is a very suitable example to take, because owing to the large mesh of the ring-trawl all the younger stages filter through and only fully grown specimens are retained. This is important, as it has been shown by Farran (3) and others that the younger individuals live higher in the water than the older, in which case the distribution figure obtained would embody two or three separate types of distribution running gradually one into the other, if the collections contained mixtures of small and large stages.

The actual numbers of each species taken on the different occasions are given in Table 2. The full details of conditions, times, and depths are to be found in a previous publication (14, pp. 149-151). If we examine in Fig. 4 the vertical distribution of Calanus on different days we notice that on April 8th, July 16th, and August 6th the types of distribution shown approximate very closely to the hypothetical distribution marked B* in Fig. 3. There are also indications of this type of distribution shown on some of the other days, but it must be remembered that errors due to irregular horizontal distribution are liable to distort any picture of the true vertical distribution. On the three days mentioned above it is very evident that samples were taken at different depths right through the vertical range of distribution of Calanus, and that one was somewhere near the region of maximum abundance. If the theory outlined above holds for Calanus finmarchicus, it would appear that the full-grown animal prefers a comparatively high light intensity, and can also exist in a considerable range of intensities.

To turn now to the vertical distribution of Cosmetira pilosella, we see from Table 2 that this species was never taken in any numbers above a depth of 20 metres in daylight. Thus it seems evident that the medusa in question shows a preference for a low light intensity : further, in Fig. 4 it can be seen that on April 29th, July 29th, and August 6th, the distribution figures were curiously symmetrical compared with those of Calanus. In fact, they approximate very nearly to the type shown as C in Fig. 3. (See also Fig. 6, p. 432, July 17th, 2.35-4.19 p.m., and 7.27-9.13 p.m., July 18th, 2.36-4.19 a.m., and July 19th, 2.28-4.6 a.m., and 7.35-9.12 a.m.)

* It will be remembered that in this hypothetical distribution, B, the optimum zone was imagined as lying midway between the maximum and minimum in light intensity units. It is quite to be expected that in nature such would not be the case, but that there would be a skew either towards the high or low intensity. From the actual distributions shown in Fig. 4 it should be possible to test such a point, if the light intensities in the region of maximum abundance, and near the upper and lower limits of the vertical distribution be known. 


\section{TABLE 2 .}

\section{Calanus finmarchicus}

$\begin{array}{ccccccccccc} & \text { April } & \text { April } & \text { April } & \text { May } & \text { June } & \text { June } & \text { July } & \text { July } & \text { July } & \text { August } \\ \text { 2nd. } & \text { 8th. } & 29 \text { th.* } & 19 \text { th. } & 4 \text { th. } & \text { 18th. } & \text { 1st. } & 16 \text { th. } & 29 \text { th. } & 8 \text { th. } \\ \text { Surface } & 868 & 20 & 16 & 6 & 50 & - & 7 & 157 & 546 & 1005 \\ & 65 \cdot 3 \% & 0 \cdot 8 \% & 0 \cdot 5 \% & 0 \cdot 3 \% & 1 \cdot 3 \% & 0 \cdot 0 \% & 0 \cdot 1 \% & 0 \cdot 9 \% & 2 \cdot 5 \% & 3 \cdot 8 \% \\ \text { II } & 183 & 1100 & 1541 & 381 & 320 & 7 & 8 & 5450 & 2260 & 10,520 \\ & 13 \cdot 8 \% & 41 \cdot 9 \% & 47 \cdot 3 \% & 17 \cdot 9 \% & 8 \cdot 2 \% & 0 \cdot 5 \% & 0 \cdot 2 \% & 33 \cdot 4 \% & 10 \cdot 4 \% & 40 \cdot 5 \% \\ \text { III } & 59 & 740 & 785 & 890 & 960 & 175 & 380 & 4140 & 5570 & 7000 \\ & 4 \cdot 5 \% & 28 \cdot 2 \% & 24 \cdot 1 \% & 41 \cdot 8 \% & 24 \cdot 7 \% & 12 \cdot 4 \% & 9 \cdot 4 \% & 25 \cdot 4 \% & 25 \cdot 3 \% & 27 \cdot 2 \% \\ \text { IV } & 59 & 488 & 820 & 250 & 1060 & 285 & 1510 & 3420 & 5470 & 4100 \\ & 4 \cdot 5 \% & 18 \cdot 6 \% & 25 \cdot 2 \% & 11 \cdot 8 \% & 27 \cdot 3 \% & 20 \cdot 3 \% & 37 \cdot 2 \% & 21 \cdot 1 \% & 24 \cdot 8 \% & 15 \cdot 9 \% \\ \text { V } & 52 & 160 & 100 & 300 & 650 & 620 & 960 & 2070 & 2670 & 1370 \\ & 4 \cdot 0 \% & 6 \cdot 1 \% & 3 \cdot 1 \% & 14 \cdot 1 \% & 16 \cdot 7 \% & 44 \cdot 0 \% & 23 \cdot 7 \% & 12 \cdot 7 \% & 12 \cdot 2 \% & 5 \cdot 3 \% \\ \text { VI } & 105 & 120 & - & 300 & 850 & 320 & 1190 & 1040 & 5480 & 1800 \\ & 7 \cdot 9 \% & 4 \cdot 6 \% & & 14 \cdot 1 \% & 21 \cdot 8 \% & 22 \cdot 7 \% & 29 \cdot 4 \% & 6 \cdot 4 \% & 24 \cdot 8 \% & 6 \cdot 9 \%\end{array}$

\section{Cosmetira pilosella.}

\begin{tabular}{|c|c|c|c|c|c|c|c|c|c|c|}
\hline Surface & $\begin{array}{l}\text { April } \\
\text { 2nd. } \\
-\end{array}$ & $\begin{array}{c}\text { April } \\
\text { 8th } \\
-\end{array}$ & $\begin{array}{l}\text { April } \\
29 \text { th* }^{2} \\
\overline{0.0 \%}\end{array}$ & $\begin{array}{l}\text { May } \\
19 \text { th. } \\
0.0 \%\end{array}$ & $\begin{array}{l}\text { June } \\
\text { 4th. } \\
0.0 \%\end{array}$ & $\begin{array}{l}\text { Junz } \\
18 \text { th. } \\
\overline{0.0 \%}\end{array}$ & $\begin{array}{l}\begin{array}{l}\text { July } \\
\text { 1st. }\end{array} \\
0.0 \%\end{array}$ & $\begin{array}{l}\text { July } \\
16 \text { th. } \\
0.0 \%\end{array}$ & $\begin{array}{l}\text { July } \\
29 \text { th. } \\
0 \cdot 0 \%\end{array}$ & $\begin{array}{l}\text { August } \\
\text { 8th. } \\
\overline{0.0} \%\end{array}$ \\
\hline II & - & - & $\overline{0.0 \%}$ & & $\overline{0.0 \%}$ & & & & & \\
\hline III & - & - & $\begin{array}{l}11 \\
1.9 \%\end{array}$ & $\overline{0.0 \%}$ & $\overline{0.0 \%}$ & $\overline{0.0 \%}$ & $\overline{0.0 \%}$ & $\begin{array}{c}1 \\
0 \cdot 2 \%\end{array}$ & $\overline{0.0 \%}$ & \\
\hline IV & - & - & $\begin{array}{l}447 \\
79 \cdot 3 \%\end{array}$ & $\overline{0.0 \%}$ & $\overline{0.0 \%}$ & $\overline{0.0 \%}$ & $\overline{0.0 \%}$ & $\begin{array}{l}173 \\
30 \cdot 4 \%\end{array}$ & $\begin{array}{l}51 \\
0.8 \%\end{array}$ & $\begin{array}{c}9 \\
1 \cdot 4 \%\end{array}$ \\
\hline V & - & - & $\begin{array}{l}106 \\
18.8 \%\end{array}$ & $\begin{array}{l}281 \\
47 \cdot 1 \%\end{array}$ & $\begin{array}{l}322 \\
25 \cdot 6 \%\end{array}$ & $\begin{array}{c}1 \\
5 \cdot 2 \%\end{array}$ & $\begin{array}{c}19 \\
36 \cdot 6 \%\end{array}$ & $\begin{array}{c}19 \\
16.5 \%\end{array}$ & $\begin{array}{l}4650 \\
79 \cdot 1 \%\end{array}$ & $\begin{array}{l}511 \\
83 \cdot 3 \%\end{array}$ \\
\hline VI & - & - & - & $\begin{array}{l}316 \\
52.9 \%\end{array}$ & $\begin{array}{l}938 \\
74 \cdot 4 \%\end{array}$ & $\begin{array}{c}18 \\
94 \cdot 8 \%\end{array}$ & $\begin{array}{c}33 \\
63 \cdot 4 \%\end{array}$ & $\begin{array}{l}301 \\
52.9 \%\end{array}$ & $\begin{array}{l}1180 \\
20 \cdot 1 \%\end{array}$ & $\begin{array}{c}94 \\
15 \cdot 3 \%\end{array}$ \\
\hline
\end{tabular}

Again applying the above argument it would appear that Cosmetira pilosella shows a preference for low light intensities, and is adapted only for a relatively small range of intensity.

Fig. 5 gives the vertical distribution of two species of copepods, Centropages typicus and Temora longicornis. It can be seen that while Temora apparently preferred a low intensity of light Centropages lived under conditions of comparatively high light intensity, and was adapted to a considerable range of intensities, the distribution figure following very closely that of B in Fig. 3 (p. 421).

\footnotetext{
* Only five depths sampled.
} 
The actual numbers of each species taken were :--

July 16th, 1925. Closing metre net.

\begin{tabular}{|c|c|c|c|c|c|c|}
\hline & $\begin{array}{c}\text { Surface. } \\
5,860\end{array}$ & $\begin{array}{c}2 \cdot 7 \mathrm{~m} . \\
11,560\end{array}$ & $\begin{array}{r}6 \cdot 5 \mathrm{~m} . \\
21,680\end{array}$ & $\begin{array}{c}25 \cdot 8 \mathrm{~m} . \\
6,980\end{array}$ & $\begin{array}{r}26 \cdot 8 \mathrm{~m} . \\
6,080\end{array}$ & $\begin{array}{c}41 \cdot 7 \mathrm{~m} . \\
1,840\end{array}$ \\
\hline & $10.9 \%$ & $21.4 \%$ & $40.1 \%$ & $13 \%$ & $11.2 \%$ & $3.4 \%$ \\
\hline n & $\begin{array}{c}40 \\
0.08 \%\end{array}$ & $\begin{array}{c}40 \\
0.08 \%\end{array}$ & $\overline{0.0} \%$ & $\begin{array}{r}5,820 \\
12 \cdot 4 \%\end{array}$ & $\begin{array}{l}11,320 \\
24 \cdot 1 \%\end{array}$ & $\begin{array}{l}29,82 \\
63 \cdot 5\end{array}$ \\
\hline
\end{tabular}

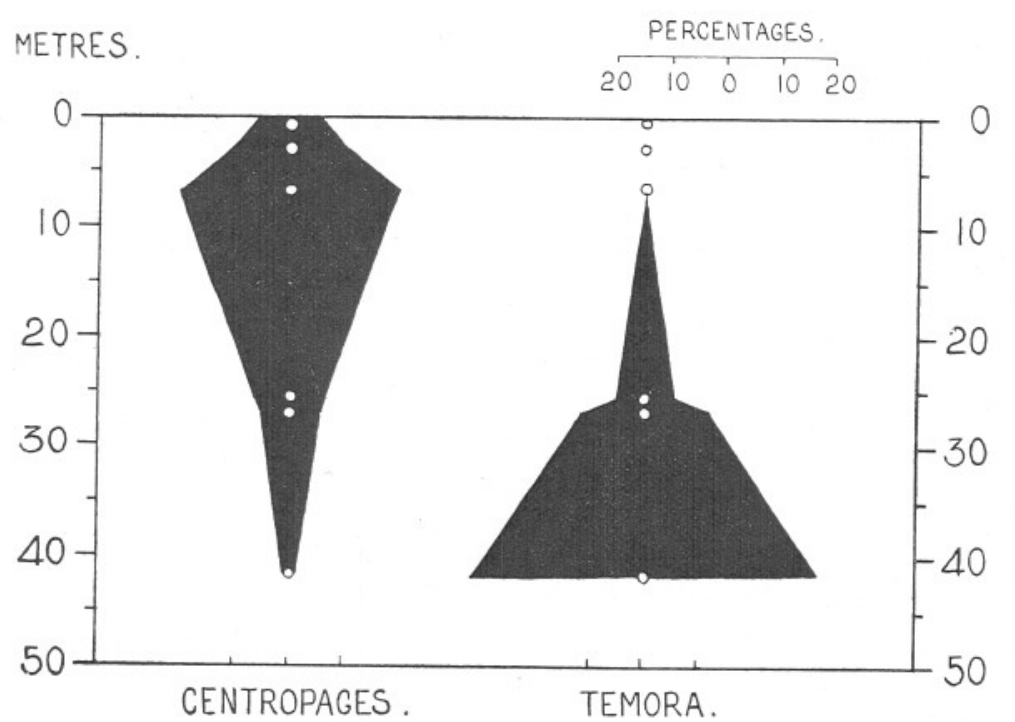

FIG. 5.-The percentage vertical distribution of Centropages typicus and Temora longicorris on July 16th, 1925, in water over 50 metres deep, as shown by collections with a closing metre net. The white spots and black circles indicate the average depths at which hauls were taken.

\section{Seasonal Variation in light Intensity correlated with ObServa- tions on seasonal changes in Vertical Distribution of certain Organisms.}

In Fig. 4 (p. 422), $\mathrm{A}$ is a curve representing the approximate change in the average midday illumination in air for each month in the year, expressed in foot candles. This curve is copied from Fig. 57 on p. 448 of the Dictionary of Applied Physics, Vol. IV, which is based on $9 \frac{1}{2}$ months' observations taken at the National Physical Laboratory from March to December, 1914. The description says that "direct sunlight was always shielded from the test cards," so that the figures may be taken as representing skylight only. 
I have, however, treated this light as direct sunlight, and estimated the light intensity at different depths in the sea in each month in the year. Since the light has been regarded as direct sunlight it has been necessary to take into consideration the altitude of the sun at different times of year, and, hence, the amount of light lost in the sea by reflection from the surface and the angle of refraction.

I am indebted to Dr. H. H. Poole for the following approximate figures from which the results have been worked :-

TABle 3.

Date.

\begin{tabular}{|c|c|c|}
\hline $\begin{array}{l}\text { Altitude of sun } \\
\text { at noon. }\end{array}$ & $\begin{array}{l}\text { Percentage of total } \\
\text { illumination trans- } \\
\text { mitted by water }\end{array}$ & $\begin{array}{l}\text { Secant of angle } \\
\text { of refraction. }\end{array}$ \\
\hline
\end{tabular}

Dec. 21st

$16^{\circ}$

$32 \%$

$1 \cdot 45$

$20^{\circ}$

$42 \%$

$1 \cdot 42$

$29^{\circ}$

$1 \cdot 33$

Oct. 21st and Feb. 21st

$40^{\circ}$

$60 \%$

$1 \cdot 22$

$52^{\circ}$

$76 \%$

$87 \%$

$60^{\circ}$

$92 \%$

$63^{\circ}$

$93 \%$

$1 \cdot 13$

$1 \cdot 08$

$1 \cdot 06$

The intensity of illumination was estimated for each month at five different depths, viz. $5,10,15,25$, and 35 metres, the formula employed being $\mathrm{I}=\mathrm{I}_{0} \mathrm{e}^{-\mu \mathrm{x}}$, where $\mu$ is the coefficient of absorption and $\mathrm{x}$ the length of the path of the rays through the water, this being the depth multiplied by the secant of the angle of refraction, which can be seen from the above table to vary for each month. The coefficients of absorption, $\mu$, were those calculated by Poole and Atkins on the occasion on which the results embodied in the curve A of Fig. 3 were obtained, they varied for different depths, being $0 \cdot 110$ from $0-10$ metres, $0 \cdot 117$ from $10-20$ metres, and $0 \cdot 133$ from 20-30 metres; this last value was used in this case also for estimating the illumination at $35 \mathrm{~m}$.

The following table gives the figures in foot candles for each month ( 1 foot candle $=10 \cdot 764$ metre candles).

\begin{tabular}{|c|c|c|c|c|c|c|c|}
\hline & Air. & $\mathrm{I}_{0}{ }^{*}$ & $I_{5}$ & $\mathrm{I}_{10}$ & $\mathrm{I}_{15}$ & $\mathrm{I}_{25}$ & $\mathrm{I}_{35}$ \\
\hline Dec. 2lst & 750 & 240 & $108 \cdot 12$ & $48 \cdot 71$ & $18 \cdot 84$ & $1 \cdot 93$ & $0 \cdot 28$ \\
\hline Nov. 21st and Jan. 21st & 1000 & 420 & $192 \cdot 35$ & $88 \cdot 06$ & $34 \cdot 75$ & $3 \cdot 74$ & 0.57 \\
\hline Oct. 21st and Feb. 21st & 1600 & 960 & $461 \cdot 96$ & $222 \cdot 28$ & $93 \cdot 02$ & $11 \cdot 53$ & $1 \cdot 96$ \\
\hline Sept. 21st and Mar. 21st & 2500 & 1900 & $971 \cdot 18$ & $496 \cdot 59$ & $223 \cdot 30$ & $32 \cdot 91$ & $6 \cdot 49$ \\
\hline Aug. 21st and April 21st & 3600 & 3132 & $1682 \cdot 3$ & $903 \cdot 44$ & $431 \cdot 13$ & $73 \cdot 10$ & $16 \cdot 27$ \\
\hline July 21 st and May 21 st & 4000 & 3680 & $2031 \cdot 9$ & $1121 \cdot 7$ & 552.98 & $101 \cdot 46$ & $24 \cdot 14$ \\
\hline June 2lst & 4100 & 3813 & $2128 \cdot 1$ & $1188 \cdot 3$ & $593 \cdot 34$ & $112 \cdot 33$ & $27 \cdot 44$ \\
\hline
\end{tabular}

* This is the illumination immediately beneath the surface, obtained by multiplying the air illumination by the percentages given in Table 3 . 
From the above figures curves were drawn for each month, and from these Fig. $4 \mathrm{~B}$ was constructed. This diagram shows the iso-intensity lines plotted against depth throughout the season. The curves naturally have no direct significance, being based on purely arbitrary figures, but they are inserted here to illustrate the principle which would appear to underlie the behaviour of certain plankton animals in the daytime throughout the seasons. In practice, of course, these curves would not be smooth, but would be extremely wavy according to variations in weather conditions, daily changes in illumination being enormous from one moment to another under certain conditions, such variations being as much as $80 \%$ in a few minutes (2, p. 449$)$.

From this diagram (B) we see then that if an animal is to be adapted to a certain light intensity we should expect it to show variations in depth throughout the year, and that it should be at its deepest at mid-day on a sunny day in the middle of June.

Fig. 4 shows the daylight distributions of Calanus finmarchicus on different days between April 2nd and August 6th, 1925. It can be clearly seen that there is a gradual descent of the region of maximum abundance from the beginning of April to June 18th, when the sun is near its maximum altitude and intensity, and that after that a gradual ascent is shown. There are evident discrepancies, but on examination of the weather conditions existing at the time the collections were made these become explained. For instance, we should not expect so marked a change in the distribution between April 2nd, when the Calanus were crowding at the surface, and April 8th, when the depth of maximum abundance was around 7 metres; but this would appear to be explained by the fact that on April 2nd the weather was very dull and overcast, and that on April 8th there was bright sunshine. Again the rise shown for July 16th to August 6th appears to be unexpectedly high, but here it is evidently due to the fact that on these occasions the weather was very dull and foggy, with mist and rain.

It can be seen from the figure that the region of maximum abundance has sunk by June 18th from very near the surface to about 20 metres; probably it would have been even deeper if the collections on June 18th had been taken at midday when the light is at its strongest: they were, however, taken between $7 \cdot 25$ and 9.3 in the morning. Now a glance at diagram $B$ shows that the intensity of 3132 foot candles occurring at the surface in April has sunk only to about 2 metres in mid-June. This is because the air illuminations on which the figures are based are skylight and not direct sunlight. If the figures had been for direct sunlight the curve $A$ would have been very much steeper, and consequently the iso-intensity lines in B would have gone deeper.

As an illustration I compare the intensities I have calculated for 
September 21st with those obtained by Poole and Atkins on October 1st, 1925. It will be seen that they agree very nearly. Both are expressed in metre candles.

\begin{tabular}{cr}
\multicolumn{2}{c}{ Theoretical Intensities, } \\
Sept. 21st. \\
Air & 26,896 \\
Just below surface & 20,446 \\
$5 \mathrm{~m}$. & 10.449 \\
$10 \mathrm{~m}$. & 5,343 \\
$15 \mathrm{~m}$. & 2,402 \\
$25 \mathrm{~m}$. & 354 \\
$35 \mathrm{~m}$. & 70
\end{tabular}

$\left.\begin{array}{cc}\multicolumn{2}{c}{\text { Actual Intensities, }} \\ \multicolumn{2}{c}{\text { Oct. 1st, } 1925 .} \\ \text { Air } & 22,400^{*} \\ 1.5 \mathrm{~m} . & 15,000 \\ 6 \cdot 1 \mathrm{~m} . & 9,280 \\ 8.9 \mathrm{~m} . & 5,770 \\ 12 \cdot 2 & 3,970 \\ 18 \cdot 3 \mathrm{~m} . & 1,450 \\ 24 \cdot 4 \mathrm{~m} . & 470 \\ 34.8 \mathrm{~m} . & 132 \\ & 94\end{array}\right\}$

The weather conditions noted for October 1st, 1925, were "Dull " and "Weak Sun." On September 3rd, however, in bright sun the air illumination was three times as great, being 68,700 metre candles (10, p. 192).

If now we examine the seasonal changes in the vertical distribution of Cosmetira pilosella, as shown in Fig. 4, it would appear that there is not so marked a change ; it is, however, difficult to tell for certain, as it is evident that on May 19th, June 4th and 18th, and July 1st the whole vertical range of distribution was not sampled. However, in Fig. 6 (p. 432), we see that in the afternoon of June 17th, between 2.35 and 4.19 p.m., the whole range was apparently sampled and the zone of maximum abundance lay around 30 metres; if the distribution on this date be compared with that for July 29th and August 6th it is obvious that the zone of maximum abundance has moved up from about $30 \mathrm{~m}$. to about $25 \mathrm{~m}$., a movement of only about 5 metres, while Calanus finmarchicus showed between July 18th and August 6th a vertical rise of nearly 20 metres of the zone of maximum abundance. If this signifies that Cosmetira has followed a certain low light intensity in its seasonal changes in depth, the small variation in its depth is contrary to expectation; because, in theory, the the iso-intensity curves for low intensities should move through a slightly greater vertical range between April and August than those for high intensities. It may, of course, be that proximity to the bottom comes in as an interfering factor, in this case it being at just over 50 metres. On the other hand, it may be an indication of the actual changes that do occur in the light intensity in the sea in these creas.

\footnotetext{
* This value varied from 16,000 to 24,500 m.c. during the series, and the values quoted here are not corrected for this, but are the observed values. The corrected values are recorded as percentages in an unnumbered table on p. 420 , plotted in Fig. 3.

$\dagger$ Surface $=24,500$ and 17,400 m.c. respectively.
} 
In the course of my investigations I have always used a small silk tow-net attached to the warp just at its junction with the bridles of the ring-trawl. The collections obtained by this net have furnished abundant evidence that the deeper layers are very much richer in plant life than the water layers nearer the surface ; this is true both of diatoms and Phæocystis, the species of diatoms, of course, varying with the seasons. This plant-life presumably has sunk down from the upper layers in which active assimilation and reproduction occurs, and must be constantly accumulating in the deeper layers (vide also Gran 5, p. 123).

Owing to the scattering of light by these countless small diatoms in suspension in sea-water the apparent coefficient of absorption of the seawater will tend to be raised, and hence it is possible that the difference in intensity in the deeper layers between the period before the diatoms are abundant and May or June may not be relatively so great as the changes that occur in the upper layers during the same season. To illustrate this point I took collections on April 9th and April 13th this year (1926) in the same region about ten miles from land. Before and after collecting I used a Secchi's disc, $20 \mathrm{~cm}$. in diameter, to ascertain the transparency of the water.

On April 9th it was cloudless, with slight haze, but the breeze was fresh so that the surface of the sea was considerably ruffled; on April 13th it was cloudless, the atmosphere was clear and at the same time the sea surface was very calm with an almost glassy smoothness. It was therefore to be expected that the light penetration of April 13th would be greater than that on April 9th, the Secchi disc, however, disappeared from sight at the following depths on the two days :-

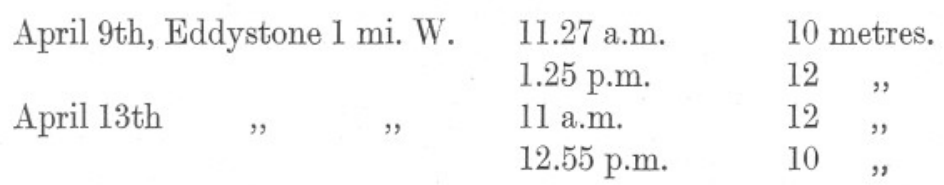

From these figures it would appear that there was possibly a great difference in the transparency at a depth of about 10-12 m. on the two days. Collections with the ring-trawl showed that, while there was a considerable amount of animal life at the surface and at about 3 metres on April 9th, it was markedly scarce in these layers on April 13th. This would perhaps indicate a higher intensity in the surface layers on the latter date than on the former; yet, how was it that the Secchi disc disappeared at approximately the same depth on the two days? The answer is probably to be found in the results shown by the small tow-net, which being of " medium " mesh (50 strands to the inch) would only show signs of diatoms in the catch if they were extremely abundant in the sea-water. 
Now the collections with this net on the two days showed the following results :-

\begin{tabular}{|c|c|c|c|}
\hline \multirow{4}{*}{$\begin{array}{l}\text { Surface } \\
3 \mathrm{~m} \\
7 \mathrm{~m}\end{array}$} & \multicolumn{2}{|l|}{ April 9th. } & April 13th. \\
\hline & No green tinge. & Surface & No green tinge. \\
\hline & ," & $3 \mathrm{~m}$. & Faint green tinge. \\
\hline & , & $13 \mathrm{~m}$. & $\begin{array}{l}\text { Deep green tinge and thic } \\
\text { catch of Phæocystis an } \\
\text { Biddulphia, etc. }\end{array}$ \\
\hline $15.5 \mathrm{~m}$. & , & $27 \cdot 6 \mathrm{~m}$ & Ditto. \\
\hline & , & $35 \cdot 4 \mathrm{~m}$ & Ditto. \\
\hline $32 \cdot 4 \mathrm{~m}$ & , & $41 \mathrm{~m}$. & Ditto. \\
\hline
\end{tabular}

The thick growth of plant-life, which started evidently somewhere between the surface and 13 metres, may have been the cause of the disappearance from view of the Secchi disc at about 10 metres on April 13th at which depth the transparency of the water would be greatly reduced. In which case the indications from the ring-trawl catches are that the upper layers had a stronger illumination on April 13th than on April 9th, while the evidence produced by the Secchi disc would indicate that on the two dates there may not have been so great a difference in the illumination at about $10-12$ metres.

A further example of the apparent large change in depth of an animal living in the upper layers throughout the season, in daylight, compared with the slight change of one living at deeper depths and lower intensities, is furnished in a previous paper (14). Here, on p. 118 is given the vertical distribution of post-larval Gadoid fishes between April 2nd and June 17th : it can be seen that the post-larvæ of Gadus merlangus, the whiting, show a marked change as the season advances, deserting the surface and upper layers as the light intensity grows. The post-larvæ of the Poor Cod, Gadus minutus, however, which apparently always lived at a low light intensity, below 20 metres, showed no marked seasonal change in their distribution in daylight.

\section{Diurnal Variation in Light Intensity and Diurnal changes in the Vertical Distribution of certain Plankton Animals.}

Apart from seasonal change in light intensity there is also a regular diurnal fluctuation, i.e. in the passage of time from midday, through the hours of darkness, to midday. Corresponding with these changes in intensity we very often find alterations in the vertical distribution of plankton animals.

Of the actual changes that do occur in the vertical distribution of plankton animals throughout the twenty-four hours in the sea little is 
at present known. The majority of records have been based on the comparison of collections from surface layers only, or other depths; such collections, while indicating that the surface layers become filled up by certain animals at night, or that some forms are taken at smaller depths at night than in the daytime, give no definite information about their actual vertical distribution at different times.

In 1924 I carried out a series of collections throughout the twenty-four hours, on a moonlight night in July ; the results showed that while some species actually crowded into the surface layers at night, depleting the lower water layers, others, apparently, merely extended their daytime distribution into the upper layers, so that they became evenly distributed from the surface downwards (13, pp. 783 and 785). Again other forms showed apparently no change in their vertical distribution throughout the hours of darkness, while many animals, living on or near the bottom in the daytime, moved up through a vertical distance of 10 or 20 metres at night (13, pp. 787 and 789). It would appear from the diagrams referred to in this previous paper (13) that those forms that were evenly distributed had lost even their minimum intensity, and were wandering anywhere through the water layers. There is an indication that they have picked up their optimum intensity at dawn and massed around it, moving down with it as the day advances. A somewhat similar suggestion* has already been put forward by Michael to explain the diurnal changes in the vertical distribution of Sagitta bipunctata in the San Diego region (9). It seems probable, however, that other factors may underlie the nocturnal habits of certain animals, as the apparent indication of no change in the vertical distribution of certain species at night cannot be explained on this hypothesis, neither can the massing of certain species right at the surface between sunset and sunrise.

In $1925 \mathrm{I}$ repeated this experiment in mid-June; at this time there was no moon. The collecting on this occasion was carried through two successive nights, so that the second night acted more or less as a control on the first. Most species showed identical types of behaviour on the two nights indicating that the methods of collecting were probably sound. It was noticeable that certain animals showed a more marked movement upwards on this moonless night than on the moonlight night in July, 1924. The full results of these collections will be given in a future paper.

In Fig. $6 \mathrm{I}$ have given the vertical distribution of three species at the different times in June, 1925. These are for the copepod Calanus finmarchicus and the medusæ, Turris pileata and Cosmetira pilosella. The actual numbers of each species taken in each haul are given in Table 4.

* He suggests that, while being attracted upwards by bright twilight conditions at dusk and dawn, at night, the twilight stimulus being removed, they return to deeper layers where they find optimum conditions of temperature, salinity, etc.

$$
\text { NEIV SERIES.-VOL. XIV NO. 2. AUGUST, } 1926 .
$$




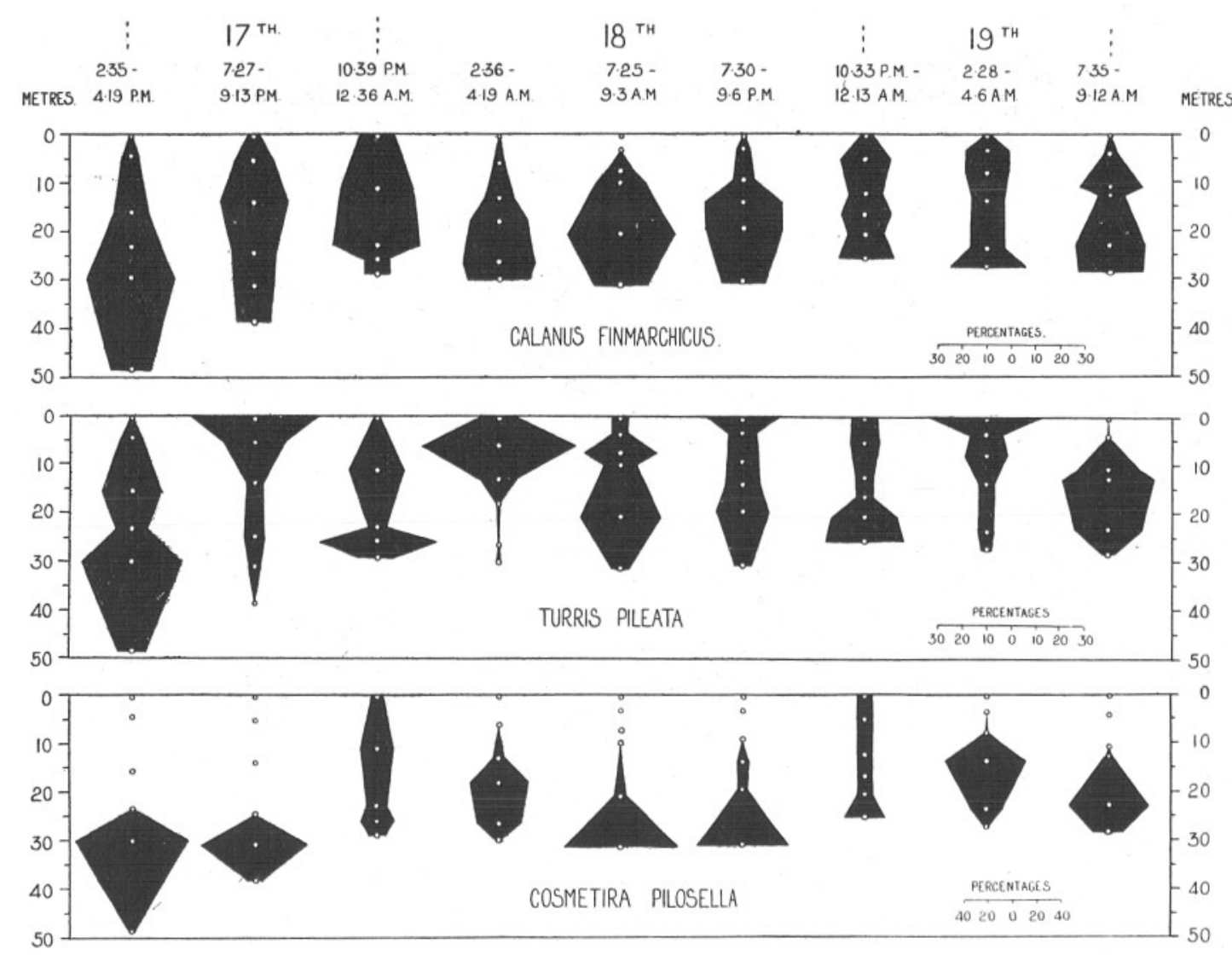

IG. 6. - The percentage vertical distribution of Calanus finmarchicus, Turris pileata, and Cosmetira pilosella, at the times shown, on June 17-18-19th, 1925. The white spots and black circles indicate the average depths at which hauls were taken. 


\section{Table 4.}

\section{Calanus finmarchicus.}

\begin{tabular}{|c|c|c|c|c|c|c|c|c|c|}
\hline & $\begin{array}{l}\text { Daylight. } \\
2.33 \text { to } \\
4.10 \mathrm{p} . \mathrm{m} .\end{array}$ & $\begin{array}{c}\text { Dusk. } \\
7.25 \text { to } \\
9.4 \text { p.m. }\end{array}$ & $\begin{array}{l}\text { Dark. } \\
10.37 \mathrm{p} . \mathrm{m} . \\
\text { to } 12.46\end{array}$ & $\begin{array}{c}\text { Dawn. } \\
2.35 \text { to } \\
4.29 \text { a.m. }\end{array}$ & $\begin{array}{l}\text { Daylight. } \\
7.22 \text { to } \\
9.14 \text { a.m. }\end{array}$ & $\begin{array}{c}\text { Dusk. } \\
7.29 \text { to } \\
9.16 \text { p.m. }\end{array}$ & $\begin{array}{c}\text { Dark. } \\
10.31 \mathrm{p} \mathrm{m} \text {. } \\
\text { to } 12.23\end{array}$ & $\begin{array}{c}\text { Dawn. } \\
2.27 \text { to } \\
4.16 \text { a.m }\end{array}$ & $\begin{array}{c}\text { Daylight. } \\
7.32 \text { to } \\
9.21 \text { a.m. }\end{array}$ \\
\hline Surface & $\begin{array}{c}40 \\
0 \cdot 7 \%\end{array}$ & $\begin{array}{l}200 \\
5 \cdot 5 \%\end{array}$ & $\begin{array}{c}\text { a.m. } \\
1330 \\
13.6 \%\end{array}$ & $\begin{array}{c}21 \\
1 \cdot 1 \%\end{array}$ & $\overline{0.0 \%}$ & $\begin{array}{c}44 \\
1 \cdot 2 \%\end{array}$ & $\begin{array}{l}\text { a.m. } \\
400 \\
4 \cdot 5 \%\end{array}$ & $\begin{array}{c}45 \\
1 \cdot 8 \%\end{array}$ & $\begin{array}{c}12 \\
0 \cdot 2 \%\end{array}$ \\
\hline II & $\begin{array}{l}410 \\
6 \cdot 9 \%\end{array}$ & $\begin{array}{c}600 \\
16 \cdot 7 \%\end{array}$ & $\begin{array}{r}2850 \\
29 \cdot 0 \%\end{array}$ & $\begin{array}{l}110 \\
5.5 \%\end{array}$ & $\begin{array}{c}7 \\
0.5 \%\end{array}$ & $\begin{array}{l}220 \\
6 \cdot 3 \%\end{array}$ & $\begin{array}{r}1840 \\
21 \cdot 3 \%\end{array}$ & $\begin{array}{c}465 \\
18 \cdot 8 \%\end{array}$ & $\begin{array}{l}314 \\
6 \cdot 2 \%\end{array}$ \\
\hline III & $\begin{array}{c}870 \\
14 \cdot 7 \%\end{array}$ & $\begin{array}{c}1010 \\
27 \cdot 6 \%\end{array}$ & $\begin{array}{r}3520 \\
36.0 \%\end{array}$ & $\begin{array}{c}235 \\
11 \cdot 8 \%\end{array}$ & $\begin{array}{c}175 \\
12 \cdot 4 \%\end{array}$ & $\begin{array}{l}330 \\
9 \cdot 4 \%\end{array}$ & $\begin{array}{c}1230 \\
14 \cdot 2 \%\end{array}$ & $\begin{array}{c}460 \\
18 \cdot 6 \%\end{array}$ & $\begin{array}{c}1260 \\
25.9 \%\end{array}$ \\
\hline IV & $\begin{array}{c}1490 \\
25 \cdot 2 \%\end{array}$ & $\begin{array}{c}690 \\
18.9 \%\end{array}$ & $\begin{array}{r}1030 \\
10 \cdot 5 \%\end{array}$ & $\begin{array}{c}480 \\
24 \cdot 2 \%\end{array}$ & $\begin{array}{c}285 \\
20 \cdot 3 \%\end{array}$ & $\begin{array}{r}1160 \\
33 \cdot 1 \%\end{array}$ & $\begin{array}{c}1810 \\
21 \cdot 0 \%\end{array}$ & $\begin{array}{c}340 \\
13 \cdot 8 \%\end{array}$ & $\begin{array}{c}570 \\
11 \cdot 8 \%\end{array}$ \\
\hline V & $\begin{array}{c}2140 \\
36 \cdot 2 \%\end{array}$ & $\begin{array}{c}640 \\
17 \cdot 5 \%\end{array}$ & $\begin{array}{r}1050 \\
10 \cdot 7 \%\end{array}$ & $\begin{array}{c}610 \\
30 \cdot 7 \%\end{array}$ & $\begin{array}{r}620 \\
44 \%\end{array}$ & $\begin{array}{r}1110 \\
31 \cdot 6 \%\end{array}$ & $\begin{array}{c}1330 \\
15 \cdot 4 \%\end{array}$ & $\begin{array}{c}360 \\
14 \cdot 6 \%\end{array}$ & $\begin{array}{c}1410 \\
28.9 \%\end{array}$ \\
\hline VI & $\begin{array}{c}970 \\
16 \cdot 2 \%\end{array}$ & $\begin{array}{c}510 \\
13 \cdot 5 \%\end{array}$ & $*$ & $\begin{array}{c}530 \\
26 \cdot 6 \%\end{array}$ & $\begin{array}{c}320 \\
22 \cdot 7 \%\end{array}$ & $\begin{array}{c}640 \\
18 \cdot 2 \%\end{array}$ & $\begin{array}{c}2000 \\
23 \cdot 2 \%\end{array}$ & $\begin{array}{c}800 \\
32 \cdot 4 \%\end{array}$ & $\begin{array}{r}1310 \\
26 \cdot 9 \%\end{array}$ \\
\hline
\end{tabular}

TURris PIleata.

$\begin{array}{cccccccccc}\text { Surface } & - & 117 & 1 & 28 & 4 & 97 & 21 & 134 & 1 \\ & 0 \cdot 0 \% & 53 \cdot 4 \% & 2 \cdot 9 \% & 15 \cdot 0 \% & 7 \cdot 8 \% & 30 \cdot 5 \% & 11 \cdot 1 \% & 48 \cdot 1 \% & 0 \cdot 4 \% \\ \text { II } & 6 & 55 & 8 & 121 & 4 & 38 & 23 & 39 & 4 \\ & 9 \cdot 7 \% & 25 \cdot 2 \% & 23 \cdot 7 \% & 64 \cdot 8 \% & 7 \cdot 8 \% & 12 \cdot 1 \% & 12 \cdot 0 \% & 14 \cdot 0 \% & 1 \cdot 7 \% \\ \text { III } & 15 & 16 & 3 & 28 & 15 & 41 & 16 & 50 & 58 \\ & 24 \cdot 6 \% & 7 \cdot 2 \% & 8 \cdot 4 \% & 15 \% & 29 \cdot 5 \% & 12 \cdot 9 \% & 8 \cdot 3 \% & 18 \cdot 0 \% & 25 \cdot 8 \% \\ \text { IV } & 8 & 18 & 17 & 3 & 7 & 48 & 16 & 19 & 86 \\ & 13 \cdot 2 \% & 8 \cdot 2 \% & 50 \% & 1 \cdot 6 \% & 13 \cdot 8 \% & 15 \cdot 1 \% & 8 \cdot 3 \% & 6 \cdot 8 \% & 38 \cdot 3 \% \\ \text { V } & 25 & 12 & 5 & 2 & 17 & 70 & 53 & 21 & 63 \\ & 41 \cdot 1 \% & 5 \cdot 3 \% & 14 \cdot 9 \% & 1 \cdot 0 \% & 33 \cdot 4 \% & 22 \cdot 1 \% & 27 \cdot 8 \% & 7 \cdot 5 \% & 28 \cdot 0 \% \\ \text { VI } & 7 & 2 & * & 5 & 4 & 24 & 62 & 16 & 13 \\ & 11 \cdot 5 \% & 0 \cdot 9 \% & & 2 \cdot 6 \% & 7 \cdot 8 \% & 7 \cdot 4 \% & 32 \cdot 5 \% & 5 \cdot 7 \% & 5 \cdot 7 \%\end{array}$

Cosmetira pilosella.

\begin{tabular}{|c|c|c|c|c|c|c|c|c|c|}
\hline Surface & $\overline{0.0 \%}$ & $\overline{0.0 \%}$ & $\begin{array}{c}20 \\
10 \cdot 9 \%\end{array}$ & $\overline{0.0 \%}$ & $\overline{0.0 \%}$ & $\overline{0.0 \%}$ & $\begin{array}{c}38 \\
11 \cdot 7 \%\end{array}$ & $\overline{0.0 \%}$ & $\overline{0.0 \%}$ \\
\hline II & $\overline{0.0 \%}$ & $\overline{0.0 \%}$ & $\begin{array}{c}53 \\
28 \cdot 7 \%\end{array}$ & $\overline{0.0 \%}$ & $-\overline{0.0 \%}$ & $\begin{array}{c}1 \\
0.3 \%\end{array}$ & $\begin{array}{c}42 \\
13 \%\end{array}$ & - & $\overline{0.0 \%}$ \\
\hline III & $\begin{array}{c}2 \\
0 \cdot 2 \%\end{array}$ & $-\overline{0.0 \%}$ & $\begin{array}{c}33 \\
17 \cdot 8 \%\end{array}$ & $\begin{array}{c}19 \\
10 \cdot 2 \%\end{array}$ & $\overline{0.0 \%}$ & $\begin{array}{c}8 \\
2 \cdot 6 \%\end{array}$ & $\begin{array}{c}41 \\
12 \cdot 6 \%\end{array}$ & $\begin{array}{c}4 \\
4 \cdot 2 \%\end{array}$ & $\overline{0.0 \%}$ \\
\hline IV & $\begin{array}{c}7 \\
0.6 \%\end{array}$ & $\begin{array}{c}1 \\
0 \cdot 3 \%\end{array}$ & $\begin{array}{c}52 \\
28 \cdot 1 \%\end{array}$ & $\begin{array}{c}91 \\
48 \cdot 7 \%\end{array}$ & $\overline{0.0 \%}$ & $\begin{array}{c}36 \\
11 \cdot 7 \%\end{array}$ & $\begin{array}{c}44 \\
13 \cdot 5 \%\end{array}$ & $\begin{array}{c}65 \\
67 \cdot 8 \%\end{array}$ & $\begin{array}{c}11 \\
8.6 \%\end{array}$ \\
\hline V & $\begin{array}{r}1217 \\
93.0 \%\end{array}$ & $\begin{array}{c}251 \\
87 \cdot 2 \%\end{array}$ & $\begin{array}{c}27 \\
14 \cdot 6 \%\end{array}$ & $\begin{array}{c}66 \\
35 \cdot 3 \%\end{array}$ & $\begin{array}{c}1 \\
5 \cdot 2 \%\end{array}$ & $\begin{array}{c}30 \\
9 \cdot 8 \%\end{array}$ & $\begin{array}{c}47 \\
14 \cdot 5 \%\end{array}$ & $\begin{array}{c}25 \\
26 \cdot 1 \%\end{array}$ & $\begin{array}{c}85 \\
66 \cdot 4 \%\end{array}$ \\
\hline VI & $\begin{array}{c}79 \\
6.0 \%\end{array}$ & $\begin{array}{c}36 \\
12 \cdot 5 \%\end{array}$ & $*$ & $\begin{array}{c}11 \\
5.9 \%\end{array}$ & $\begin{array}{c}18 \\
94 \cdot 8 \%\end{array}$ & $\begin{array}{c}233 \\
75 \cdot 7 \%\end{array}$ & $\begin{array}{c}113 \\
34 \cdot 8 \%\end{array}$ & $\begin{array}{c}2 \\
2.0 \%\end{array}$ & $\begin{array}{c}32 \\
25 \cdot 0 \%\end{array}$ \\
\hline
\end{tabular}


the details of time, depths, etc., are given in another publication in this volume of the Journal (15, p. 388). It can be seen from Fig. 6 that the behaviour of Calanus finmarchicus differed in June, 1925, from that shown for July, 1924, see Fig. 6 on p. 791 of the previous publication (13). The figure shows that there was apparently merely an extension of the distribution into the surface layers on June 17th at "dusk" and "dark," * and similarly at "dark" and "dawn" on the 18th and 19th, whereas in July, 1925, there was a massing at the surface at "dusk," an even distribution from surface downwards at " dark," and an apparent accumulation round an optimum intensity at about 10 metres at "dawn." The differences between the two observations may possibly be correlated with differing intensities occurring at different times of the year.

Turris pileata, which, in 1924 (13, p. 783), showed a massing at the surface at midnight, in 1925, as shown by Fig. 5, tended to mass at the surface at dusk and dawn apparently seeking the deeper layers again at night. It should here be noted that the day distributions at 2.35 to 4.19 p.m. on June 17 th and 7.25 to 9.3 a.m. on June 18 th are probably misleading; they can be seen from Table 4 to be based on too low figures. It is probable, however, that that shown for 7.35 to 9.12 a.m. on June 19th represents more nearly the true daylight distribution.

The results obtained for Cosmetira pilosella are very clearly defined: the figure speaks for itself, and shows that about midnight these medusæ were evenly distributed from the surface downwards, and that at dawn they appeared to be massed around an optimum intensity, which they followed downwards as the daylight increased in strength.

The behaviour of these three species of plankton animals has been inserted here to illustrate how the diurnal changes in light intensity probably play an important part in controlling the behaviour of some plankton animals from day to day. It is, however, evident that a very much larger number of observations of this type must be made at all times of the year, before we can hope to arrive at the true significance of these diurnal changes in vertical distribution.

\section{DISCUSSION.}

Let us now consider the various external factors that may be of importance in controlling the behaviour of these plankton animals in this region.

Rose, in an admirable paper on the biology of plankton (12), comes to the following general conclusion. The majority of pelagic animals are adapted to an optimum intensity of light. Each species, and even each

* There is an indication that there may have be nn a depletion of layers below about 25 metres, but unfortunately the catch from the deeper layers was lost through the net striking the bottom. 
individual, may have its own characteristic optimum intensity. Each animal, further, is affected by numerous physico-chemical factors, either external or internal in origin. The optimum zone of distribution changes with the age of the animal and its physico-chemical state at any moment, and rises or falls according to a number of external or internal factors which may interfere, such factors being temperature, hydrogen ion concentration, salinity, etc. Rose gives his factors the following order of importance :-

1. Light, which, under average conditions, has clearly a predominating influence.

2. Temperature, which becomes very important and can even overwhelm the effect of light when it passes $20^{\circ}$.

3. Other factors of the medium (concentration, aeration, etc.).

It is then very evident that my observations in the field tend to confirm Rose's ideas.

In considering the vertical distribution of plankton animals there are two factors that must always be borne in mind.

1. The geographical locality. Factors may exert a powerful influence in one latitude, that in another region may have little effect.

Rose experimented in the laboratory with copepods both from Roscoff in the English Channel and Banyuls-sur Mer on the Mediterranean coast. He noticed that the temperature zone between about $20^{\circ}$ and $25^{\circ}$ was of considerable importance for many of the species examined, in that, between these points there lay critical temperatures at which phototropism was reversed and at which different species of copepods, which were uniformly distributed in jars containing water of lower temperatures, crowded to the bottom of the vessel in which they were living (12, pp. 485 and 512). Further, this held good for copepods both from Roscoff and Banyuls-sur-Mer. In the Channel the highest temperature reached by the upper 5 or 6 metres in the summer is just over $16^{\circ}$; it would seem unlikely, then, that high temperature would play an important part in the behaviour of certain plankton animals in this region ; on the other hand, the surface waters of the Mediterranean may reach so high a temperature as $27^{\circ}$ in the summer, in that region therefore high temperature might well be considered a factor of great importance in the behaviour of plankton animals in the sea. M. Rose has also expressed a similar opinion to me by letter.

2. The type of environment. Just as variations in certain factors may be of a sufficient range to become important in controlling the behaviour of certain animals in one geographical region, but not in another, as, for instance, temperature, so in the same manner a factor may or may 
not have importance in different types of environment in the same locality. In confined spaces such as ponds and rock pools the changes that occur in the water are extreme compared to those in the open sea. For instance, Atkins $(1$, p. 768$)$ found that the seasonal changes of $\mathrm{pH}$ and temperature in the following two environments were:-

$\begin{array}{lccc} & \mathrm{pH} & \mathrm{pH} \text { Range. } & \text { Temperature. Temperature } \\ \text { Range. } & \\ \text { Rock Pool } & 8 \cdot 57-8 \cdot 01 & 0 \cdot 56 & 21 \cdot 4^{\circ}-8 \cdot 2^{\circ} \mathrm{C} . \quad 13 \cdot 2^{\circ} \mathrm{C} \text {. } \\ \text { E1, 20 miles S.W. of } & 8 \cdot 27-8 \cdot 14 & 0 \cdot 13 & 16 \cdot 2^{\circ}-9 \cdot 9^{\circ} \mathrm{C} . \quad 6 \cdot 3^{\circ} \mathrm{C} \text {. }\end{array}$

Plymouth Breakwater

In shallow water round the shore the variations in such factors are also more extreme than in the open sea.

My observations were made in the neighbourhood of the Eddystone Lighthouse, where the conditions do not differ essentially from those existing at the International Station, E1 ; if anything the ranges of the various factors are very slightly greater in this region. It has been noted that the $\mathrm{pH}$ variation is $8 \cdot 27-8 \cdot 14$, such changes are so slight as to be of doubtful importance in affecting the behaviour of such plankton animals as are discussed in this paper; the salinity range is in the neighbourhood of $35 \cdot 40-35 \cdot 13^{\circ}$ oo (1, p. 768$)$. It remains then to discuss the possible effect of temperature change throughout the season; this in the surface layers is quite considerable, amounting to $6^{\circ}$ or $7^{\circ}$.

In Fig. 7 is given the change in temperature that took place twenty miles from the coast throughout the year 1925, the same year in which the seasonal observations of plankton animals given in this paper were made. The figure has been based on the following temperature observations (Table 5) for which I am indebted to Mr. H. W. Harvey :---

\section{TABLE 5.}

Station E1. Lat. $50^{\circ} \cdot 02^{\prime}$ N. G.L. $4^{\circ} \cdot 22^{\prime}$ W. Depth, 74 m.

Depth Jan. Feb. March April May June July Aug. Aug. Oct. Nov. Dec. in 19th. 17th. 14th. 22nd. 13th. 3rd. 8th. 5th. 31st. 1st. 11th. 11th. metres.

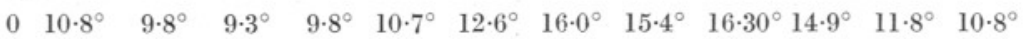

$5 \quad 10 \cdot 79^{\circ} 10 \cdot 01^{\circ} 9 \cdot 24^{\circ} 9 \cdot 69^{\circ} 10 \cdot 5^{\circ} 11 \cdot 95^{\circ} 15 \cdot 75^{\circ} 15 \cdot 22^{\circ} 16 \cdot 30^{\circ} 14 \cdot 50^{\circ}-$

$10 \quad 10 \cdot 79^{\circ}-\quad 9 \cdot 19^{\circ} \quad 9 \cdot 47^{\circ} 10 \cdot 3^{\circ} \quad 10 \cdot 92^{\circ} 14 \cdot 3^{\circ} \quad 15 \cdot 10^{\circ} 15 \cdot 75^{\circ} 14 \cdot 00^{\circ} 12 \cdot 8^{\circ} \quad 10 \cdot 97^{\circ}$

$1510 \cdot 79^{\circ} 10 \cdot 01^{\circ} 9 \cdot 19^{\circ} 9 \cdot 44^{\circ} 9 \cdot 99^{\circ}$ - $12 \cdot 03^{\circ} 14 \cdot 90^{\circ} 14 \cdot 93^{\circ} 13 \cdot 83^{\circ}$ —

20 - $-\quad$ - $\quad-9.96^{\circ} 10 \cdot 55^{\circ} 11 \cdot 85^{\circ} 13 \cdot 15^{\circ} 13 \cdot 40^{\circ} 13 \cdot 70^{\circ} 12 \cdot 85^{\circ} 10 \cdot 97^{\circ}$

$2510 \cdot 79^{\circ} 10 \cdot 01^{\circ} 9 \cdot 18^{\circ} 9 \cdot 44^{\circ}$ - — - $12 \cdot 02^{\circ} 13 \cdot 32^{\circ}$ - -

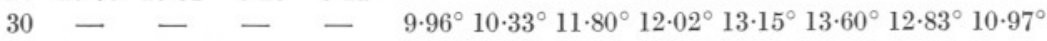

$40-6-6-13.58^{\circ}-$ - -

$50 \quad 10 \cdot 79^{\circ} 10 \cdot 01^{\circ} 9 \cdot 16^{\circ} 9 \cdot 44^{\circ} 9 \cdot 96^{\circ} 10 \cdot 00^{\circ} 11 \cdot 80^{\circ} 12 \cdot 01^{\circ} 12 \cdot 80^{\circ} 13 \cdot 59^{\circ} 13 \cdot 00^{\circ} 10 \cdot 97^{\circ}$ ca. $70 \quad 10 \cdot 79^{\circ} 10 \cdot 01^{\circ} 9 \cdot 16^{\circ} 9 \cdot 44^{\circ} \quad 9 \cdot 95^{\circ} 10 \cdot 00^{\circ} 11 \cdot 80^{\circ} 12 \cdot 00^{\circ} 12 \cdot 80^{\circ} 13 \cdot 57^{\circ} 13 \cdot 05^{\circ} 10 \cdot 97^{\circ}$ 
It can be seen, both from Fig. 7 and the table, that the surface temperature was rising steadily from the middle of March until August 31st, when it reached a maximum of $16 \cdot 30^{\circ} \mathrm{C}$. If temperature were the factor that drove certain plankton animals from the surface in summer it would be expected that the forms living in the upper layers would be at their maximum depth towards the end of August. Actually results showed

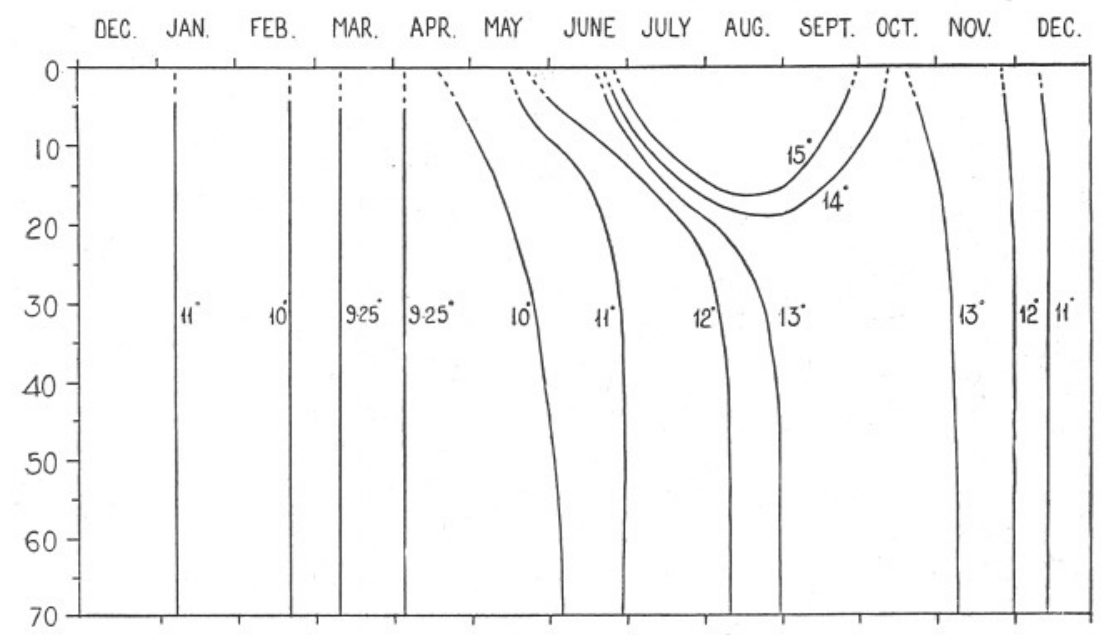

FIG. 7.-Diagram showing the seasonal changes of temperature that occurred at all depths at the international station, El, in the year 1925. The depths are in metres, and degrees are Centigrade.

that they were deepest in mid-June when the light intensity was presumably at its highest, and that in July and August, when the temperature was still rising, they were higher in the water.

These observations point to the apparent paramount importance of light intensity - and by that we must understand certain compositions of light, owing to the selective absorption of sea-water-in controlling the behaviour of certain plankton animals.

That the slight changes occurring in other factors have no effect is by no means expected. It is necessary first to obtain actual readings of light intensity at different depths throughout the season correlated with plankton collections made at the same time as the light measurement. It should be possible then to find if the optimum intensity chosen by an animal at any one time remains constant throughout the season, or whether other factors may intervene to change it. The necessity for laboratory experiments on the effects of different factors on animals kept under varying light intensities is evident. Experiments employing light of the various compositions likely to be met with at different depths in the sea would be of great interest. 
In this respect it is interesting to speculate on the possible importance played by the longer ultra-violet rays. It may well be that if these rays are present above a certain concentration they may exert a harmful or even lethal effect on certain organisms. The harmful effects of short ultra-violet rays in too great quantities on the higher animals is well known, and one would naturally suppose that plankton animals, which for the most part are transparent and have no direct pigmentary protection from the penetration of light rays, are especially susceptible. Huntsman ( $\mathbf{y})$ has demonstrated the destructive action of sunlight on Calanus finmarchicus, Meganyctiphanes norvegica, Thysanoèssa inermis, and other plankton species, and suggests that "the bathymetric distribution of such forms will be determined by the amount of sunlight in any region, and the distance to which it penetrates the water." Fox (5) also found that ultra-violet rays were the most active in causing Echinoderm larvæ and Paramoecium to seek the bottom of a jar lighted from the side.

Knudsen (8) found, by a spectro-photographic method, that the absorption in sea-water of the violet end of the spectrum was even more marked than that of the red rays, and that the green penetrated farthest. Grein (6), however, demonstrated the presence of ultra-violet rays (3C0$400 \mu \mu)$ at great depths, up to 1000 metres and more. It is a significant fact that Knudsen worked in water $9 \mathrm{~m}$. deep in the Nyborg Fjord, while Grein made his observations in depths of over $1500 \mathrm{~m}$. in the Mediterranean. The effect of fine particles in suspension on scattering light of small wave lengths is great and it is probably in this fact that the explanation lies as to the apparent disagreement of Grein's and Knudsen's results. In shallow waters and waters near to the coast the amount of matter in suspension is very great as compared with ocean water far from land. Close to land then the effect will be to increase the apparent coefficient of absorption of the shorter wave-length rays. In the case of Knudsen's observations the optimum wave-length for penetration was found to be in the green portion of the spectrum, $510 \mu \mu$. From this point in the spectrum the coefficient of absorption increased towards the red end, due to the actual absorption of these rays by the sea-water; a similar and more marked increase was also shown towards the violet end, presumably in this case this was to a large extent apparent absorption, due to the scattering of the short wave-length rays by particles in suspension. It seems then quite permissible to suppose that as one moves away from the coast and its turbid waters to the clearer and purer water of the open sea there will be a gradual increase in penetration along the spectrum from the region of the green towards the violet and ultraviolet, until very nearly the maximum amount of ultra-violet light is able to penetrate. In pure water, free from particles in suspension, 
there is hardly any absorption of the green end of the yellow light, $558 \mu \mu$; the absorption of ultra-violet is, however, much greater. Raman (11, p. 53) quotes figures found by Count Aufsess, showing that for pure water selective absorption in the visual region ceased for wave-lengths less than $558 \mu \mu$, the coefficients of absorption for the two wave lengths, $522 \mu \mu$ and $494 \mu \mu$, being 0.00002. Shelford and Gail (16, p. 157), in a table showing the transmission of light of different wave-lengths by pure water, give the maximum penetration as being in the region of 537 $\mu \mu$, and they give for ultra-violet light $(300 \mu \mu)$ a penetration slightly greater than that for orange, $600.5 \mu \mu$. It seems then probable that in the region in which I have carried out my plankton observations, ten miles from the coast, that the presence of a certain amount of ultra-violet light is to be expected in the upper water layers.

I should like to take this opportunity of thanking Dr. E. J. Allen F.R.S., and the Staff of this laboratory for much assistance; I am also especially indebted to Dr. H. H. Poole, Dr. W. R. G. Atkins, F.R.s., Mr. H. W. Harvey, and Mr. C. F. A. Pantin, for helpful criticism and advice.

\section{SUMMARY.}

1. Results of collections with the ring-trawl to obtain evidence on the vertical distribution of plankton animals in daylight at different times of the year and at night are given.

2. The vertical distribution of Calanus finmarchicus and Cosmetira pilosella is discussed in relation to the distribution of light intensity in the sea.

3. Results show that light intensity is apparently the external factor of greatest importance in determining the vertical distribution of these plankton animals in this region.

4. Many more observations at sea correlated with simultaneous records of light intensity at different depths are required, together with laboratory experiments on the effects of various factors on the behaviour of plankton animals kept under different conditions of light intensity.

\section{LITERATURE CITED.}

1. Atrins, W. R. G. The Hydrogen Ion Concentration of Sea-water in its Biological Relations. Journ. Mar. Biol. Assoc., Vol. XII, No. 4, p. 717. 1922.

2. Dictionary of Applied Physics. Vol. IV. Light: Sound: Radiology. Edited by Sir Richard Glazebrook. Macmillan and Co. 1923. 
3. Farran, G. P. Bulletin Planktonique, Pt. II, p. 84. 1911.

4. Fox, H. M. The Effect of Light on the Vertical Movement of Aquatic Organisms. Proc. Cambridge Philos. Soc., Vol. I, No. 4, p. 219. 1925.

5. Gran, H. H. The Plankton Production of the North European Waters in the Spring of 1912. Bulletin Planktonique. 1912.

6. Grein, K. Untersuchungen über die Absorption des Lichts im Seewasser. Zweiter Teil. Ann. de l'Inst. Océanogr., Tome VI, Fasc. 6. 1914.

7. Huntsman, A. G. Limiting Factors for Marine Animals. 1, The Lethal Effect of Sunlight. Contributions to Canadian Biology, N.S., Vol. 2, No. 4.1925.

8. Knudsen, M. On Measurement of the Penetration of Light into the Sea. Cons. Perm. Intern. pour l'Explor. de la Mer. Public. de Circonstance. No. 76. 1922.

9. Michael, E. L. Classification and Vertical Distribution of the Chætognatha of the San Diego Region. Univ. Cal. Publ. Zool., Berkeley, Vol. VIII, No. 3, pp. 21-186. 1911.

10. Poole, H. H., and Atkins, W. R. G. On the Penetration of Light into Sea-water. Journ. Mar. Biol. Assoc., Vol. XIV, No. 1, p. 177.1926.

11. Raman, C. V. Molecular Diffraction of Light. Published by the University of Calcutta. 1922.

12. Rose, M. Contribution à l'Étude de la Biologie du Plankton. Le Problème des Migrations Verticales Journalières. Archives de Zool. Expér. et Gener., Tome 64, Fasc. 5, p. 387. 1925.

13 Russell, F. S. The Vertical Distribution of Marine Macroplankton. An Observation on Diurnal Changes. Journ. Mar. Biol. Assoc., Vol. XIII, No. 4, p. 769. 1925.

14. Russell, F. S. The Vertical Distribution of Marine Macroplankton. II. The Pelagic Young of Teleostean Fishes in the Daytime in the Plymouth Area, with a note on the eggs of certain Species. Journ. Mar. Biol. Assoc., Vol. XIV, No. 1, p. 101. 1926.

15. Russell, F. S. The Vertical Distribution of Marine Macroplankton. III. Diurnal Observations on the Pelagic Young of Teleostean Fishes in the Plymouth Area. Journ. Mar. Biol. Assoc., Vol. XIV, No. 2, p. 387. 1926.

16. Shelford, V. E., ANd GAIL, F. W. A Study of Light Penetration into Sea-water made with the Kunz Photo-Electric Cell with Particular Reference to the Distribution of Plants. Publications Puget Sound Biological Station, Vol. 3, Nos. 64-67, p. 129. 1922 . 